\section{Análise do Programa Le Chat}

\author{
J. P. LEAL*
}

Apesar do enorme interesse que os computadores têm despertado a nivel do ensino, a quantidade de programas a ele dedicados nomeadamente em Química, concebidos e apresentados em português, ainda é reduzida. É por isso natural que 0 aparecimento de mais programas de Química em português, seja sempre uma boa notícia. Ainda para mais quando, alguns deles possuem uma qualidade que os torna comparáveis ao que de melhor se faz noutros paises, ditos mais avançados. Está de parabéns o Projecto SoftCiências.

Passemos então à análise do programa propriamente dito. Num primeiro ecrã aparece-nos um gato (Le Chat) bastante engraçado. assim como um menú em que são apresentados os vários tipos de reacções que podem ser seleccionados (Tabela 1). Três delas são de tipo geral, sendo as outras três casos concretos. A diferença entre ambos os tipos reside apenas no facto de que para os casos concretos não se pode alterar o valor da constante de equilibrio.

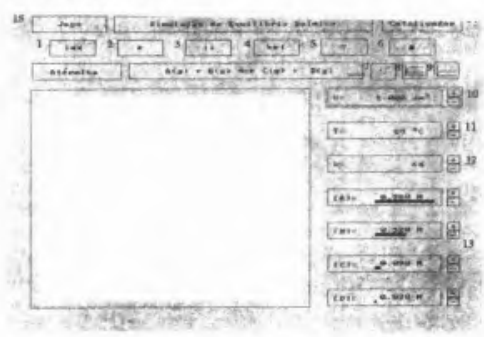

Ecrã principal do programa Le Chat

Uma vez efectuada a escolha entramos no segundo ecrã, onde toda a actividade se desenrola (Figura I). Não sei se é totalmente original, mas, dispor as teclas de comando do avanço, recuo ou paragem da reacção (1-4, Fig.l) como os comandos de um vulgar gravador audio, parece-me uma ideia engenhosa. Facilita enormemente a memorização das funções.

Para cada uma das reacçôes podemos alterar o volume (10, Fig.l), a temperatura (11, Fig.I) ou a constante de equilibrio (12, Fig.I ) e

\section{Livros recebidos}

- F. H. Jardine, How to do your Student Project in Chemistry, Chapman \& Hall, Londres, 1994 (110 pp.)

- F. Horácio Sousa, Quimicomagia, Almedina, Coimbra, 1994 (97 pp.) ver qual 0 efeito produzido na reacção. Esta visualização pode ser feita "seguindo" as moléculas como pontos coloridos no ecră (7, Fig.l), vendo a evolução das concentrações das várias espécies envolvidas (8, Fig.l) ou seguindo a evolução do quociente da reacção ao longo do tempo (9, Fig.I). Pode ainda adicionar-se um catalisador e ver qual o efeito que ele produz, não alterando 0 estado final, mas sim a velocidade com que ele é atingido. As concentrações das espécies envolvidas são permanentemente apresentadas como barras coloridas (13, Fig.l) e em qualquer momento podem ser alteradas, seguindo-se depois a reacção do sistema a essa alteração (Principio de Le Chatelier).

Embora o programa tenha sido pensado para funcionar com rato, não foi descurado 0 facto de muitos computadores mais antigos ainda 0 não possuirem. A substituição por comandos no teclado não torna 0 programa pesado, continuando a ser agradável trabalhar com ele.

Uma utilização extremamente fácil, 0 seu aspecto sóbrio e a sensação de estarmos num jogo, tornam o programa muito apelativo, sendo uma excelente ferramenta para ver como as reacçōes se comportam "ao vivo".

É ainda de realçar o manual que se encontra simples, mas completo para um programa deste tipo. Destacam-se as Palavras-Chave (uma série de conceitos relacionados com equilibrio e com o Principio de Le Chatelier e que são sumariamente explicados quer no manual quer na ajuda interactiva no próprio programa), os três roteiros (dois para alunos do $10^{\circ}$ ano e um outro para $012^{\circ}$ ano, e que guiam os alunos numa visita muito instrutiva pelo programa e suas potencialidades) e finalmente uma pequena bibliografia de Henri Louis Le Chatelier. Uma última nota para referir que está prevista para futuras versões uma opção de jogo em que 0 aluno tentará adivinhar qual será a evolução antes de a visualizar no monitor.

Uma apreciação global do programa, só pode ser muito positiva.

\section{correspondên ci a}

Li com agrado "Quatro horas de Química" (Química 53 (1994) 56). Verifiquei contudo que dos nomes citados por Camilo, apenas se davam elementos sobre Orfila. Compreende-se que não se tenha feito o mesmo com Berzelius e Liebig, pois são sobejamente conhecidos.

Porém, e aliás justificadamente, embora pelo motivo oposto, isso também aconteceu com o lente de Quimica da Academia Politécnica, Joaquim de Santa Clara de Sousa Pinto. Julgo, que apesar de tudo seria interessante
Quaisquer questões poderẫo ser enviadas para a sede da SPQ ao cuidado do autor desta análise. 0 programa Le Chat foi posto à disposição da SPQ pelo projecto SoftCiências, e está na sede da Sociedade à disposição dos sócios que 0 pretendam consultar antes de 0 adquirirem.

\begin{tabular}{lr}
\hline A NOSSA CLASSIFICAÇÃO: & \\
\hline Cálculo & - \\
Gráficos & 5 \\
Interacção com o utilizador & 5 \\
Impressão & - \\
Manual & 4 \\
\hline
\end{tabular}

1-Mau, 2-Sofrivel, 3-Razoável, 4-Bom, 5-Muito bom

\section{Necessidades de Hardware:}

IBM PC ou compativel com placa EGA (ou VGA). É fornecido numa disquete de alta densidade (3"1/2), e pode funcionar a partir da mesma. No entanto, a existência de um disco rigido facilita as operaçōes em termos de velocidade. 0 rato, sem ser necessário, também facilita a interacção com 0 utilizador.

\section{Fornecedor:}

Projecto SoftCiência, Coimbra (ver: Química 52 (1994) 8).

Preço (1994):

$2000 \$ 00$ (sócios SPQ,SPF,SPM)

$2500 \$ 00$ (não sócios)

1- Dep Química, ICEN-INETI, Sacavém.

TABELA 1 - EQUAÇÕES QUIMICAS DISPONIVEIS

$\begin{array}{ll}1 & \mathrm{~A}+\mathrm{B} \Leftrightarrow \mathrm{C}+\mathrm{D} \\ 2 & \mathrm{~A}+\mathrm{B} \Leftrightarrow \mathrm{C}+2 \mathrm{D} \\ 3 & 2 \mathrm{~A}+3 \mathrm{~B} \Leftrightarrow 2 \mathrm{C}+\mathrm{D} \\ 4 & \mathrm{~N}_{2}+3 \mathrm{H}_{2} \Leftrightarrow 2 \mathrm{NH}_{3} \\ 5 & 2 \mathrm{SO}_{3} \Leftrightarrow 2 \mathrm{SO}_{2}+\mathrm{O}_{2} \\ 6 & \mathrm{~N}_{2} \mathrm{H}_{4}+\mathrm{O}_{2} \Leftrightarrow \mathrm{N}_{2}+2 \mathrm{H}_{2} \mathrm{O}\end{array}$

* Dep. Química, ICEN-INETI, Sacavém

saber-se que este ex-frade (como diz Camilo) era irmão de um reitor famoso (Conselheiro Basílio Alberto) e de um lente de Matemática, ambos da Universidade de Coimbra, e que foi autor de duas obras de Química, Sinonymia Chimica ou nomes antigos e modernos dos productos chimicos mais usados (Porto, 1844 ) e Noções gerais e elementares de Chymica theorica e pratica, traduzidas e coordenadas... (Porto, 1856).

Um leitor identificado 


\section{ERRATA}

$\begin{array}{cccc}\text { Página } & \text { Coluna } & \text { Onde está } & \text { Deve ler-se } \\ 1 & 3 & \text { José Empif } & \text { José Empis } \\ 28 & 1 & \mathrm{E}=\mathrm{h} \gamma & \mathrm{E}=\mathrm{hv} \\ 28 & 3 & \mathrm{Na} \ldots \text { apresenta-se } & \text { Na Figura } 1 \text { apresenta-se } \\ 65 & \text { Quadro III } & \text { péptidios } & \text { péptidos }\end{array}$

